\title{
In Silico Studies, Synthesis and Biological Evaluation of 4,5-Dehydrospisulosine Butyrate Ceramides as Potential Sphingosine Kinase I Inhibitors
}

\section{Parleen Kaur}

Punjab Engineering College: PEC University of Technology

Sonia Sharma

Panjab University

Vinay Randhawa

Panjab University

Navneet Agnihotri

Panjab University

Ramandeep Kaur

Panjab University

vasundhara singh ( $\square$ vasun7@yahoo.co.in )

PEC University of Technology https://orcid.org/0000-0001-8639-2313

\section{Research Article}

Keywords: 4,5-dehydrospisulosine, Cross metathesis reaction, In silico analysis, Sphingosine Kinase I inhibitors

Posted Date: May 28th, 2021

DOI: https://doi.org/10.21203/rs.3.rs-552974/v1

License: (c) (i) This work is licensed under a Creative Commons Attribution 4.0 International License. Read Full License 


\section{Abstract}

In the present work, synthesis of 4,5-dehydrospiulosine and its chain analogues (1-3) as potential Sphingosine Kinase I inhibitors has been achieved via the diasteroselective Grignard reaction, stereoselective cross metathesis reaction followed by $\mathrm{N}$-acylation with $\mathrm{p}$-nitrophenyl butyrate to give the corresponding butyrate ceramides (4-6). All compounds were obtained in high yield and purity followed by molecular docking simulation studies using AutoDock which indicated their varying binding affinities with Sphingosine Kinase 1 protein was done. Further, the biological evaluation studies, as potential antiprostate cancer agents by inhibiting the sphingosine kinase 1 protien of all synthesized compounds (1-6) on PC-3 cell lines by SRB method was done. Compound N-((2S,3S,E)-3 hydroxyheptadec-4-en-2-yl) butyramide (4) exhibited remarkable cytotoxicity with an $\mathrm{IC}_{50}$ value of $6.06 \mu \mathrm{M}$.

\section{Introduction}

Sphingolipids are highly bioactive compounds that modulate many cell signalling pathways that are relevant to tumour biology and cancer control. The ceramide analogues of sphingolipids act as the inhibitor of cell growth and hence lead to apoptosis. Sphingosine 1-phosphate (S1P), inhibits apoptosis, induces cell migration and other pro-carcinogenic behaviours. ${ }^{1,2}$ However, sphingosine, sphinganine, and other sphingoid bases also have the potential to be useful for cancer control, because they inhibit transformation of normal cells induced by different sources. The effectiveness of sphingoid bases have a limitation as it is phosphorylsed by sphingosine kinase-an enzyme that has been called an oncogene. Recent literature has shown interest towards targeting sphingosine kinase for cancer therapy. SK1 has been a primary target with a hope to suppress the ceramide/S1P rheostat in an attempt to regulate cell growth. On the basis of this rationale, one would predict that compounds that cannot be phosphorylated would be more effective in cancer suppression than the naturally occurring sphingoid base sphingosine. ${ }^{2}$

In the recent past, interest in deoxysphingolipids has evolved due to the lack of the $\mathrm{C} 1-\mathrm{OH}$ group responsible for phosphorylation and also have shown promising biological activity. ${ }^{2}$ The interest has further been accelerated with studies of naturally extracted Fumonisin $\mathrm{B}^{3}$ (Fig. 1.) that acts as inhibitors of ceramide synthase, a key enzyme in the sphingolipid biosynthetic pathway. ${ }^{4,5}$ Delgado et al. ${ }^{6}$ reported a sterioselective synthesis of Spisula polynyma Spisulosine(Fig. 1.) spisulosine and its analogues along with its 4,5-dehydrospisulosine(Fig. 1.) analogues for analysing the role of ceramide synthase and their resulting products in cell fate. These group of antiproliferative compounds of marine origin isolated from the clam and its different chain analogues have also been reported ${ }^{7,8}$ as an inhibitor of sphingosine kinase, resulting in lower levels of endogenous S1P. Spisolusine was initially developed as anticancer agent due to its ability to inhibit proliferation in the prostate tumor PC-3 and LNCaP cell lines ${ }^{8}$ but later discontinued from phase I in 2008. ${ }^{10,11}$ The other closely related structure such as obscuraminols, ${ }^{7,8}$ claviminols, ${ }^{9,10}$ xestoaminols ${ }^{11}$ (Fig. 1.) have also shown remarkable cytotoxic propterties. In addition, recent evidence of the presence of 1-deoxysphingolipids in human sensory 
neuropathy type 1 (HSN1) $)^{12}$ and for the metabolic syndrome such as type 2 diabetes as a novel class of biomarkers, has also been reported. ${ }^{12}$

The chemical composition of this important class of compounds includes long lypophilic carbon chain, vicinal amino alcohol with defined syn/anti stereochemistry 8,9 , variable number of unsaturation on the lipophilic backbone with defined cis/trans stereochemistry, presence of amidic linkage with short and long chain fatty acids ${ }^{10}$ and other additional functionalities as illustrated in (Fig. 1.). The design and synthesis of new sphingosine kinase inhibitors as anti cancer agents are interesting target for organic chemists. Further the in silico studies support the rationale behind the design the new chemical entities by calculating the binding conformations with respect to amino acid interaction, hydrogen bonding and hydrophobic interaction between the ligand and protein.

Ceramide serves as a central mediator in sphingolipids metabolism and signaling pathways, regulating many fundamental cellular responses. They are referred to as a 'tumor suppressor lipid'. Recently, many studies have focused on the ceramide-induced apoptosis pathway and mitochondria dependent apoptosis. Structurally the ceramide molecule contains a sphingoid long-chain base backbone, linked to a fatty acid molecule through an amide bond. Two main approaches to promote anticancer activity in the ceramide-Sph-S1P axis have been identified as use of an exogenous supplement of ceramide to promote apoptosis and inhibition of cermaide-metabolizing enzymes to regulate the ceramide /S1P rheostat. Few short chain ceramide have lead to promising anti-cancer effects due to its more solubility as compared to long chain fatty acids. Thus in most studies mostly short chain ceramides but not naturally occurring ceramides have been used as potential anti-cancer agents. ${ }^{13}$

Ceramide molecules contains a long sphingoid chain backbone, linked to a fatty acid molecule through an amide bond with a 4,5-trans double bond. In the present work, keeping in view of the main structural features required and also inspired by the potential biological significance of deoxysphingolipids as cancer therapeutics with varying structural features we have undertaken the design of few 4,5dehydrospisulosine and its chain analogues (1-3) followed by a small library of their corresponding butyrate ceramides (4-6) as Sphingosine Kinase I inhibitors via the diasteroselective Grignard reaction, stereoselective cross metathesis reaction followed by $\mathrm{N}$-acylation in good yield and purity. The choice of butyric acid is based on the known anti cancer activity of short chain ceramides ${ }^{14}$ itself and can also present an added advantage as chemopreventive agents which may result due to the partial hydrolysis of the ceramide. The in silico studies of the binding conformations with respect to amino acid interaction, hydrogen bonding and hydrophobic interaction between the ligand and protein for the proposed compounds was done. Further the in vitro study on PC-3 cell lines by SRB method has been evaluated.

\section{Result And Discussion}

Molecular docking is one of the widely implemented approaches for the study of protein-ligand interactions and for drug discovery and development. For molecular docking simulation of the compounds, the position and size of ligand-binding site were determined based on the receptor-bound 
SKI-II inhibitor in the crystal structure of SPHK1. The information of respective amino acid residues were obtained from the literature associated with the respective PDB structure [PMID: 23602659]. ${ }^{14}$ The lipidbinding pockets, called ligand binding pocket henceforth, encompass amino acid residues $\mathrm{ILE}_{174} ; \mathrm{ASP}_{178} ; \mathrm{VAL}_{177} ; \mathrm{PHE}_{192,173,303,288} ; \mathrm{THR}_{196} ; \mathrm{LEU}_{259,299,302,268,261,319} ; \mathrm{HIS}_{311} ;$ MET $_{272,306} ; \mathrm{ALA}_{274}$.

Molecular docking studies were carried out with all the proposed molecules $(1-6)$ in order to find their optimal conformations into the ligand binding pocket of SPHK1. Before commencing prospective molecular screening, the docking protocol was benchmarked by comparing the experimental and computationally predicted conformations of inhibitor SKI-II from the crystal complex (PDB ID: 3VZB), which is measured by computing the root mean square deviation (RMSD) between experimentally observed ligand conformation and the one predicted by algorithm. RMSD between experimental and computationally predicted best conformation was $1.581 \AA$, which is usually in the range $1.5-2 \AA$ [PMID: 15937897], ${ }^{14}$ which confirmed the accuracy of docking protocol for predicting the reliable binding conformations of all compounds. Physicochemical properties of the all the synthesized compounds is presented in Table 1.

Table 1

Physiochemical properties of the compounds.

\begin{tabular}{|c|c|c|c|c|c|c|}
\hline Compounds & M.Wt & $\begin{array}{l}\mathrm{H}- \\
\text { AcceptorCount }\end{array}$ & $\begin{array}{l}\mathrm{H}- \\
\text { DonorCount }\end{array}$ & $X \log P$ & $\begin{array}{l}\text { Polar surface } \\
\text { area }\end{array}$ & $\begin{array}{l}\text { Binding } \\
\text { energy } \\
\text { (Kcal/mol) }\end{array}$ \\
\hline 1 & 283.4 & 2 & 2 & 3.86 & 46.25 & $\begin{array}{l}-5.48 \\
\mathrm{kcal} / \mathrm{mol}\end{array}$ \\
\hline 2 & 269.4 & 2 & 2 & 3.62 & 46.22 & $\begin{array}{l}-4.80 \\
\mathrm{kcal} / \mathrm{mol}\end{array}$ \\
\hline 3 & 311.3 & 2 & 2 & 5.73 & 46.28 & $\begin{array}{l}-4.90 \\
\mathrm{kcal} / \mathrm{mol}\end{array}$ \\
\hline 4 & 339.5 & 2 & 2 & 3.96 & 49.32 & $\begin{array}{l}-5.89 \\
\mathrm{kcal} / \mathrm{mol}\end{array}$ \\
\hline 5 & 353.5 & 2 & 2 & 4.14 & 49.33 & $\begin{array}{l}-4.02 \\
\mathrm{kcal} / \mathrm{mol}\end{array}$ \\
\hline 6 & 381.6 & 2 & 2 & 4.61 & 49.34 & $\begin{array}{l}-5.61 \\
\mathrm{kcal} / \mathrm{mol}\end{array}$ \\
\hline
\end{tabular}

From Table 1 it is inferred that in case of compound (1-3) with one carbon increase or decrease in lipophilic chain, the $\mathrm{C}_{17}$ chain analogue (1) has showed the lower binding energy of $5.48 \mathrm{Kcal} / \mathrm{mol}$. Similarly in compounds (4-6) also, the corresponding ceramide $\mathrm{C}_{17}$ analogue (4) has showed the lowest binding energy of $-5.89 \mathrm{Kcal} / \mathrm{mol}$ among all the synthesized compounds. The docking studies of compound (4) has showed interaction via a hydrogen bond with binding site residue ILE ${ }_{174}$ (Fig. 2.) along 
with two strong hydrogen bonds with $\mathrm{Asp}_{178}$ at a distance of $2.7 \AA$. The compound (4) also exhibited 9 hydrophobic contacts with protein receptor with residues $\mathrm{PHE}_{173}, \mathrm{ILE}_{174}, \mathrm{VAL}_{177}, \mathrm{PHE}_{192}, \mathrm{VAL}_{290}, \mathrm{LEU}_{299}$, $\mathrm{LEU}_{302}, \mathrm{PHE}_{303}, \mathrm{LEU}_{319}$ at distances of $3.05 \AA$, $3.09 \AA$, $3.38 \AA$, $3.67 \AA$, $3.19 \AA$, $3.91 \AA$, $3.24 \AA$, $3.33 \AA$, 3.52, respectively as shown in Table 2. Also a hydrophobic contact with $\operatorname{Thr}_{196}$ as shown in Fig. 2. was observed and is a critical and important binding site residue due to its prime involvement in establishing SKI-II-SPKH1 complex [PMID: 23602659].

Table 2

Interactions of the compound 4 (N-((2S,3S,E)-3 hydroxyheptadec-4-en-2-yl) butyramide) with protein amino acid residues.

\begin{tabular}{|lllllll|}
\hline Compounds & $\begin{array}{l}\mathrm{H}- \\
\text { Acceptor } \\
\text { Count }\end{array}$ & $\begin{array}{l}\mathrm{H}- \\
\text { Donor } \\
\text { Count }\end{array}$ & XlogP & $\begin{array}{l}\text { Binding } \\
\text { Energy, } \Delta \mathrm{G} \\
\text { (Kcal/mol) }\end{array}$ & $\begin{array}{l}\text { Residues } \\
\text { involved in } \\
\text { Hydrogen } \\
\text { bonding }\end{array}$ & $\begin{array}{l}\text { Residues involved in } \\
\text { Hydrophobic interactions }\end{array}$ \\
\hline $\mathbf{4}$ & 3 & 3 & 3.96 & -5.89 & ILE 174 & $\begin{array}{l}\text { PHE173, ILE174, VAL177, } \\
\text { PHE192, VAL290, } \\
\text { LEU299, LEU302, } \\
\text { PHE303, LEU319 }\end{array}$ \\
\hline
\end{tabular}

\subsection{Chemistry}

Our synthetic approach, utilizes a reaction sequence starting from commercially available HNBoc amino ester $\mathbf{8}$, which was successively treated with diisobutylaluminum hydride (DIBAL) and vinylmagnesium bromide in a one-pot reaction to yield vinyl alcohols $9 a / 9 b$ as syn: anti isomers ( $d r=75: 25)$. The spectral analysis was in agreement as reported in literature wherein the syn diastereoselectivity has been established by the chelation-controlled Cram cyclic model. ${ }^{20}$ For easy separation the mixture of alcohols was converted to corresponding chromatographically separable tert-butyldimethylsilyl ethers $10 \mathrm{a}$ and $10 \mathrm{~b}$ giving the major isomer $10 \mathrm{a}$ followed by treatment with $46 \%$ hydrofluoric acid in acetonitrile regenerated the pure alcohol $9 \mathrm{a}$. The compound $9 \mathrm{a}$ obtained was subjected to olefin metathesis using Grubbs 2nd generation catalyst and respective alkenes to obtain compounds (1113) as a colorless oil followed by deprotection with $1 \mathrm{~N} \mathrm{HCl}$ in dioxane to obtain intermediates (13) which on purification were further subjected to $\mathrm{N}$-acylation using $\mathrm{p}$-nitrophenyl butyrate leading to compound (4-6) in good yield after column chromatography as illustrated in Scheme 1. All the synthesized compounds were characterized by ${ }^{1} \mathrm{H}$ NMR, ${ }^{13} \mathrm{C}$ NMR, MS, CHN analysis along with the optical rotation.

\subsection{In vitro biological evaluation}

The effect of chain length and butyrate ceramide formation on Human Prostate cancer cell toxicity was tested in vitro using sulforhodamine-B (SRB) assay. Androgen independent prostate cancer cells (PC-3) were treated for $48 \mathrm{hr}$ with compound (1-3) and their ceramides (4-6) as 1:1 molar complex with fatty 
acid free bovine serum albumin. The concentration dependent cytotoxic effect of these compounds was screened in vitro at various concentrations ie. $100 \mu \mathrm{M}, 50 \mu \mathrm{M}, 25 \mu \mathrm{M}, 12.5 \mu \mathrm{M}$ and $6.25 \mu \mathrm{M}$, respectively. From Fig. 3. it is evident that among the compound (1-3) compound (2) shows higher cytotoxicity while among the corresponding ceramide (4-6), compound (4) displayed the best cytotoxicity result.

Compound $4\left(\mathrm{~N}-\left((2 \mathrm{~S}, 3 \mathrm{~S}, \mathrm{E})-3\right.\right.$ hydroxyheptadec-4-en-2-yl) butyramide), the shorter chain $\mathrm{C}_{17}$ ceramide analogue exhibited good cytotoxic activity against PC-3 cell line with the $\mathrm{IC}_{50}$ value of $6.06 \mu \mathrm{M}$ as shown in Table 3. Hence, it is observed that by shortening of sphingoid backbone and keeping the 4, 5- trans double bond intact with an amide linkage, plays an important role in promoting cytotoxic acitivity (Fig. 3.).

Table 3

Cytotoxicity assay data of compound 4

\begin{tabular}{|llllll|}
\hline Conc. $(\mu \mathrm{M})$ & AVG & sd & live cells & dead cell & \% error \\
\hline 100 & 0.06775 & 0.007932 & 5.32345 & 94.67655 & 11.70775 \\
\hline 50 & 0.1265 & 0.00526 & 21.15903 & 78.84097 & 4.158033 \\
\hline 25 & 0.176667 & 0.02318 & 34.68104 & 65.31896 & 13.12101 \\
\hline 12.5 & 0.18175 & 0.017056 & 36.05121 & 63.94879 & 9.384473 \\
6.25 & 0.2365 & 0.016523 & 50.80863 & 49.19137 & 6.986347 \\
\hline
\end{tabular}

In vitro results corroborate the observations of molecular docking studies and suggest the anticancer potential of compound (4). The balance between the levels of interconvertible sphingosine-1-phosphate and ceramide is a crucial determinant of cell fate. Sphingosine-1- phosphate promotes cell proliferation while ceramide is pro-apoptogenic and arrest cell growth. This sphingolipid rheostat is regulated by the action of SPHK1. Inhibition of SPHK1 may lead to ceramide accumulation and cause cell death in the cancer cell lines. In the current study the hypothesis suggest that the $\mathrm{C}_{17}$ ceramide analogue (4) incorporates itself in the complex sphingolipids pathway and thereby, modulate the signaling cascades involved in carcinogenesis. Earlier reports have shown that the 4,5dehydrospisolusine ceramides have been synthesized and used as probes for profiling ceramide synthase activities in intact cells. ${ }^{15}$ Studies have also utilized $C_{17}$ ceramide analogues to probe the sphingolipid metabolism and have shown to be efficiently taken up by the cells and converted to complex sphingolipids. ${ }^{16}$ However, further work needs to be carried out to prove our hypothesis and understand the mechanism of action of these compounds.

\section{Conclusion}

We have successfully demonstrated the design strategy for the 4,5-dehydrospiulosine with varying lypophylic chain and their corresponding butyrate ceramide based on the docking studies with sphingosine kinase I protien. A short route under ambient reaction condition for deoxysphingosine and 
their ceramide (1-6) has been achieved via sterioselective Grignard and olefin metathesis reaction along with N-Acylation as the key steps. The biological evaluation of the small library of compounds (1-6) on PC-3 cell line has shown that compound (4) (N-((2S,3S,E)-3 hydroxyheptadec-4-en-2-yl) butyramide) exhibited cytotoxicity with $\mathrm{IC}_{50}$ value of $6.06 \mu \mathrm{M}$. Further in vivo studies of the synthesized compounds for understanding the mechenism is underway.

\section{Material And Experimental Details}

\subsection{Molecular docking simulations}

\section{Software and docking}

Docking computations were performed using the empirical free energy function and the Lamarckian genetic algorithm in Autodock 4 that provides the estimated free binding energy, which is the sum of intermolecular energy, total internal energy, torsional free energy, and energy of the unbound system [PMID:19399780]. Intermolecular interactions between receptor and ligands were assessed using ProteinLigand Interaction Profiler (PLIP) web-server [PMID: 25873628][15] while the images were rendered in PyMol software (pymol.org).

Preparation of protein structure and ligands

Crystal structures of protein sphingosine kinase (PDB ID: 3VZB) (also called receptor) [PMID: 23602659] was retrieved from RCSB-Protein Data Bank (PDB; www.rcsb.org/pdb) while the chemical structures of all 12 small molecules (also called ligands) were sketched and 3D optimized with ChemDraw software (www.perkinelmer.com).

Docking methodology

The intermolecular interactions between receptor and ligands was done by a three-step computational approach that included (i) receptor- and ligand-preparation, (ii) defining the grid box, (iii) molecular docking, and (iv) assessing the intermolecular interactions. AutoDockTools and AutoDock v 4.2.0 (ADT) [PMID: 19399780] program was used to perform all molecular docking simulation studies. The docking studies were carried out with all the proposed ligand molecules in order to find their optimal conformations into the ligand binding pocket of SPHK1.

\subsection{Chemicals and intsruments}

The ${ }^{13} \mathrm{C}$ and ${ }^{1} \mathrm{H}$ NMR spectra were obtained on a Bruker Avance-400 spectrometer operating at 100 and $400 \mathrm{MHz}$, respectively. Chemical shifts are downfield relative to TMS. The couplings are given in $\mathrm{Hz}$. Mass spectra were performed on a Thermo Q-Exative GC Orbitrap mass spectrometer (Thermo Fisher Scientific, Bremen, Germany). 
To a solution of allyl alcohol 9a (0.500 g, 1 equiv) dry DCM (8ml) was added desired alkene (4 equiv) and later added $2^{\text {nd }}$ generation Grubbs catalyst ( 0.03 equiv). The solution was refluxed for 6 hours. The volatilities were removed and the product was column purified by silicagel column chromatography (Hexane:Ethylacetate $=95: 5)$ yielding colorless oil (11-13) in good yield.

\section{Tert-butyl ((2S,3S,E)-3-hydroxyheptadec-4-en-2-yl) carbamate 11}

Tert-butyl((2S,3S,E)-3-hydroxyheptadec-4-en-2yl)carbamate was obtained by following the general method as colorless oil. Yield: $70 \%$.

IR (neat) cm-1:3452, 2972, 2854, 1690, 1672, 1465, 1454, 1390, 1351, 1291, 1144.

${ }^{1} \mathrm{H} \mathrm{NMR}\left(400 \mathrm{MHz}, \mathrm{CDCl}_{3}\right): \delta 5.68(\mathrm{~m}, 1 \mathrm{H}), 5.49(\mathrm{~m}, 1 \mathrm{H}), 4.66(\mathrm{~d}, 1 \mathrm{H}), 3.95(\mathrm{~d}, 1 \mathrm{H}), 3.64(\mathrm{br} \mathrm{s}, \mathrm{NH}), 2.19(\mathrm{br} \mathrm{s}$, $\mathrm{OH}), 2.04(\mathrm{~m}, 2 \mathrm{H}), 1.44(\mathrm{~s}, 9 \mathrm{H}), 1.29(\mathrm{~m}, 24 \mathrm{H}), 1.13(\mathrm{~d}, 3 \mathrm{H}), 0.89(\mathrm{t}, 3 \mathrm{H})$.

${ }^{13} \mathrm{C} \mathrm{NMR}\left(100 \mathrm{MHz}, \mathrm{CDCl}_{3}\right) \delta 13.9,14.14,17.61,21.5,28.7,28.9,29.1,29.3,29.4,29.5,31.8,32.3,53.4$, 129.2, 134.0.

MS: $\left[\mathrm{C}_{22} \mathrm{H}_{43} \mathrm{NO}_{3}+\mathrm{H}\right]^{+} 370.21$

\section{Tert-butyl ((2S,3S,E)-3-hydroxyoctadec-4-en-2-yl) carbamate 12}

Tert-butyl ((2S,3S,E)-3-hydroxyoctadec-4-en-2-yl)carbamate was obtained by following the general method as colorless oil. Yield: $72 \%$.

IR (neat) $\mathrm{cm}^{-1}: 3452,2975,2854,1710,1670,1465,1454,1390,1365,1255,1170$.

${ }^{1} \mathrm{H} \mathrm{NMR}\left(400 \mathrm{MHz}, \mathrm{CDCl}_{3}\right): \delta 5.71(\mathrm{~m}, 1 \mathrm{H}), 5.40(\mathrm{~m}, 1 \mathrm{H}), 4.61(\mathrm{~d}, 1 \mathrm{H}), 4.02(\mathrm{~s}, 1 \mathrm{H}), 3.67(\mathrm{t}, 1 \mathrm{H}), 2.0(\mathrm{~m}, 2 \mathrm{H})$, $1.33(\mathrm{~s}, 9 \mathrm{H}), 1.25(\mathrm{~m}, 25 \mathrm{H}), 1.23(\mathrm{~d}, 3 \mathrm{H}) .{ }^{13} \mathrm{C}$ NMR $\left(100 \mathrm{MHz}, \mathrm{CDCl}_{3}\right) \delta$ 14.1, 22.6, 24.6, 26.2, 29.1, 29.2, $29.3,29.4,29.5,31.8,32.3,62.2,65.1,74.0,80.9,94.3,128.2,130.3,154.2$.

MS: $\left[\mathrm{C}_{25} \mathrm{H}_{49} \mathrm{NO}_{3}+\mathrm{H}\right]^{+} 384.3001$.

\section{Tert-butyl ((2S,3S,E)-3-hydroxyicos-4-en-2-yl) carbamate 13}

Tert-butyl((2S,3S,E)-3-hydroxyheptadec-4-en-2yl)carbamate was obtained by following the general method as colorless oil. Yield: $75 \%$.

IR (neat) $\mathrm{cm}^{-1}: 3450,2971,2733,1771,1680,1499,1462,1400,1322,1231,1181$.

${ }^{1} \mathrm{H} \mathrm{NMR}\left(400 \mathrm{MHz}, \mathrm{CDCl}_{3}\right): \delta 5.11(\mathrm{~m}, 1 \mathrm{H}), 5.39(\mathrm{~m}, 1 \mathrm{H}), 4.77(\mathrm{~d}, 1 \mathrm{H}), 4.11(\mathrm{~s}, 1 \mathrm{H}), 3.62(\mathrm{t}, 1 \mathrm{H}), 2.12(\mathrm{~m}, 2 \mathrm{H})$, $1.31(\mathrm{~s}, 9 \mathrm{H}), 1.23(\mathrm{~s}, 28 \mathrm{H}), 0.88(\mathrm{t}, 3 \mathrm{H})$. 
${ }^{13} \mathrm{C}$ NMR $\left(100 \mathrm{MHz}_{\mathrm{CDCl}}\right)$ ) $14.1,22.6,24.6,26.2,29.1,29.2,29.3,29.4,29.5,31.8,32.3,62.2,65.1,74.0$, $80.9,94.3,128.2,130.3,154.2$.

MS: $\left[\mathrm{C}_{32} \mathrm{H}_{43} \mathrm{NO}_{3}+\mathrm{H}\right]^{+} 412.3121$

General method for the synthesis of Deoxysphingosines (1-3) and its corresponding ceramides (4-6)

To the solution of the intermediate (11-13) $(0.200 \mathrm{~g}$, 1 equiv) in 1,4-Dioxane $(3 \mathrm{ml})$ was added $1 \mathrm{M} \mathrm{HCl}$ $(3 \mathrm{ml})$ and stirred at $100^{\circ} \mathrm{C}$ for $1 \mathrm{~h}$. The reaction was quenched by $1 \mathrm{~N} \mathrm{NaOH}(0.5 \mathrm{ml})$ and the product was extracted in $\mathrm{DCM}(3 \times 5 \mathrm{ml})$ leading to compound (1-3). Further the deoxysphingosines (1-3) were subjected to $\mathrm{N}$-Acylation by adding p-nitrophenyl butyrate in THF for $12 \mathrm{~h}$. The product was extracted in ethyl acetate and was purified by silica gel column chromatography (Hexane:Ethylacetate $=85: 15$ ) yielding a colourless oil (4-6) respectively in good yield and purity.

\section{(2S,3S,E)-2 aminoheptadec-4-en-3-ol 1}

(2S,3S,E)-2 aminoheptadec-4-en-3-ol was obtained as a colorless oil. Yield: 90\%.

$[\mathrm{a}]_{\mathrm{D}}^{25}=+3.2(\mathrm{MeOH}) \mathrm{IR}($ neat $) \mathrm{cm}^{-1}: 3452,2975,2854,1710,1670,1465,1454,1390,1365,1212,1070$.

${ }^{1} \mathrm{H}$ NMR (400 MHz, CDCl $)$ : $\delta 5.72(\mathrm{~m}, 1 \mathrm{H}), 5.44(\mathrm{~m}, 1 \mathrm{H}), 3.78(\mathrm{~m}, 1 \mathrm{H}), 3.28(\mathrm{~m}, 3 \mathrm{H}), 2.05(\mathrm{t}, 2 \mathrm{H}), 1.25(\mathrm{~m}$, $20 \mathrm{H}), 1.13(\mathrm{~d}, 3 \mathrm{H}), 0.89(\mathrm{t}, 3 \mathrm{H})$.

${ }^{13} \mathrm{C} \mathrm{NMR}\left(100 \mathrm{MHz}, \mathrm{CDCl}_{3}\right): \delta 138.4,134.3,129.1,77.3,51.3,34.0,31.9,29.9,29.7,29.6,29.3,22.7,20.2$, 13.1.

MS: $\left[\mathrm{C}_{18} \mathrm{H}_{37} \mathrm{NO}-\mathrm{OH}\right]^{+} 252.5328,\left[\mathrm{C}_{17} \mathrm{H}_{35} \mathrm{NO}+\mathrm{H}\right]^{+} 270.5559$

\section{(2S,3S,E)-2 aminooctadec-4-en-3-ol 2}

(2S,3S,E)-2 aminooctadec-4-en-3-ol was obtained as colorless oil. Yield: 90\%.

$[\mathrm{a}]_{\mathrm{D}}^{25}=+3.1(\mathrm{MeOH}) \operatorname{IR}($ neat $) \mathrm{cm}^{-1}: 3452,2975,2854,1710,1670,1465,1454,1390,1365,121,1255$, 1170 . 
${ }^{1} \mathrm{H} \mathrm{NMR}\left(400 \mathrm{MHz}, \mathrm{CDCl}_{3}\right): \delta 5.75(\mathrm{~m}, 1 \mathrm{H}), 5.40(\mathrm{~m}, 1 \mathrm{H}), 4.13(\mathrm{~m}, 2 \mathrm{H}), 3.77(\mathrm{t}, 1 \mathrm{H}), 3.64(\mathrm{~d}, 2 \mathrm{H}), 2.05(\mathrm{~d}, 2 \mathrm{H})$, $1.37(\mathrm{~d}, 2 \mathrm{H}), 1.25(\mathrm{~m}, 25 \mathrm{H}), 1.12(\mathrm{~d}, 3 \mathrm{H}), 0.89(\mathrm{t}, 3 \mathrm{H})$.

${ }^{13} \mathrm{C} \operatorname{NMR}\left(100 \mathrm{MHz}, \mathrm{CDCl}_{3}\right): \delta 134.3,128.21,129.1,77.3,51.3,34.0,31.9,29.9,29.7,29.6,29.3,22.7,20.2$, 14.1.

MS: $\left[\mathrm{C}_{18} \mathrm{H}_{37} \mathrm{NO}-\mathrm{OH}\right]^{+} 266.5690\left[\mathrm{C}_{18} \mathrm{H}_{37} \mathrm{NO}+\mathrm{H}\right]^{+} 284.2469$

\section{(2S,3S,E)-2 aminoicos-4-en-3-ol 3}

(2S,3S,E)-2 aminoicos-4-en-3-ol was obtained as a colorless oil. Yield: $90 \%$.

a] ${ }^{25}=+3.5(\mathrm{MeOH})$. IR (neat) $\mathrm{cm}^{-1}: 3452,2975,2854,1710,1670,1465,1454,1390,1365,1255,1170$.

${ }^{1} \mathrm{H} \mathrm{NMR}\left(400 \mathrm{MHz}, \mathrm{CDCl}_{3}\right): \delta 5.61(\mathrm{~m}, 1 \mathrm{H}), 5.59(\mathrm{~m}, 1 \mathrm{H}), 4.14(\mathrm{~m}, 2 \mathrm{H}), 3.70(\mathrm{~m}, 1 \mathrm{H}), 2.62(\mathrm{~m}, 2 \mathrm{H}), 1.89(\mathrm{~s}$, $28 \mathrm{H}), 0.89(\mathrm{~d}, 3 \mathrm{H})$.

${ }^{13} \mathrm{C}$ NMR (100MHz, $\left.\mathrm{CDCl}_{3}\right): \delta 134.3,129.1,77.3,51.3,34.0,31.9,29.9,29.7,29,5$ 29.6, 29.3, 28.1, 22.7, $20.2,14.1$.

MS: $\left[\mathrm{C}_{20} \mathrm{H}_{41} \mathrm{NO}+\mathrm{H}\right]^{+} 312.3222$

\section{$N-((2 S, 3 S, E)-3$ hydroxyheptadec-4-en-2-yl) butyramide 4}

$\mathrm{N}-((2 \mathrm{~S}, 3 \mathrm{~S}, \mathrm{E})-3$ hydroxyheptadec-4-en-2-yl) butyramide was obtained as a colorless oil. Yield: $67 \%$.

$[\mathrm{a}]^{25}{ }_{\mathrm{D}}=+2.6(\mathrm{MeOH}) . \mathrm{IR}$ (neat) $\mathrm{cm}^{-1}: 3391,2812,2699,2122,1700,1680,1465,1451,1392,1361,1310$, $1255,1170$.

${ }^{1} \mathrm{H}$ NMR: (400 MHz, CDCl3): $\delta 5.76(\mathrm{~m}, 1 \mathrm{H}), 5.47(\mathrm{~m}, 1 \mathrm{H}), 4.15(\mathrm{~d}, 1 \mathrm{H}) 4.00(\mathrm{~d}, 1 \mathrm{H}), 2.21(\mathrm{~m}, 2 \mathrm{H}), 2.03(\mathrm{~m}, 2 \mathrm{H})$, $1.66(\mathrm{~m}, 2 \mathrm{H}), 1.32-1.25(\mathrm{br} \mathrm{s}, 20 \mathrm{H}), 1.07(\mathrm{~d}, 2 \mathrm{H}), 1.19(\mathrm{~d}, 2 \mathrm{H}), 0.96(\mathrm{~d}, 3 \mathrm{H}) 0.88(\mathrm{t}, \mathrm{J}=6.6 \mathrm{~Hz}, 6 \mathrm{H})$.

${ }^{13} \mathrm{C}$ NMR $\left(100 \mathrm{MHz}, \mathrm{CDCl}_{3}\right): \delta$ 173.1, 134.22, 129.3, 126.2, 78.2, 76.2, 51.8, 39.0, 37.8, 32.1, 29.6, 29.5, $26.1,22.9,18.3,14.3$.

MS: $\left[\mathrm{C}_{21} \mathrm{H}_{41} \mathrm{NO}_{2}+1\right]^{+} 340.53,\left[\mathrm{C}_{20} \mathrm{H}_{43} \mathrm{NO}_{2}+\mathrm{Na}^{+}\right]^{+} 362.48$

CHN: $\mathrm{C}=74.28, \mathrm{H}=12.17, \mathrm{~N}=4.13, \mathrm{O}=9.42$. 


\section{$N-((2 S, 3 S, E)-3$ hydroxyoctadec-4-en-2-yl) butyramide 5}

$\mathrm{N}-((2 \mathrm{~S}, 3 \mathrm{~S}, \mathrm{E})-3$ hydroxyoctadec-4-en-2-yl) butyramide was obtained as a colorless oil. Yield: $61 \%$.

$[\mathrm{a}]_{\mathrm{D}}^{25}=+2.7(\mathrm{MeOH}) . \mathrm{IR}$ (neat) $\mathrm{cm}^{-1}: 3391,2812,2772,2122,1700,1680,1465,1451,1392,1361,1310$, $1255,1170$.

${ }^{1} \mathrm{H}$ NMR: (400 MHz, CDCl3): $\delta 8.23(\mathrm{~s}, 2 \mathrm{H}), 6.01-5.6(\mathrm{~m}, 2 \mathrm{H}) 3.78-3.74(\mathrm{~m}, 3 \mathrm{H}), 2.5(\mathrm{~m}, 2 \mathrm{H}), 1.56(\mathrm{~m}, 2 \mathrm{H})$, $1.32-1.25(\mathrm{br} \mathrm{s}, 28 \mathrm{H}), 0.89(\mathrm{t}, \mathrm{J}=6.6 \mathrm{~Hz}, 6 \mathrm{H})$.

${ }^{13} \mathrm{C} \mathrm{NMR}\left(100 \mathrm{MHz}, \mathrm{CDCl}_{3}\right): \delta 160.1,121.1,125.2,77.5,75.3,51.6,39.0,37.8,32.1,29.6,29.8$ 29.5, 26.1, $25.2,22.9,18.3,14.3$.

MS: $\left[\mathrm{C}_{22} \mathrm{H}_{43} \mathrm{NO}_{2}-\mathrm{OH}^{+}\right]^{+} 337.1089,\left[\mathrm{C}_{22} \mathrm{H}_{43} \mathrm{NO}_{2}+\mathrm{H}^{+}\right] 354.3470,\left[\mathrm{C}_{22} \mathrm{H}_{43} \mathrm{NO}_{2}+\mathrm{Na}^{+}\right]^{+} 376.52$

CHN: $\mathrm{C}=74.73, \mathrm{H}=12.26, \mathrm{~N}=3.96, \mathrm{O}=9.05$.

\section{$N-((2 S, 3 S, E)-3$ hydroxyicos-4-en-2-yl) butyramide 6}

$\mathrm{N}-\left((2 \mathrm{~S}, 3 \mathrm{~S}, \mathrm{E})-3\right.$ hydroxyicos-4-en-2-yl) butyramide 6 was obtained as a colorless oil. Yield: $70 \%$. $[\mathrm{a}]^{25}{ }_{\mathrm{D}}=$ +2.7 (MeOH). IR (neat) cm-1:3391, 2812, 2772, 2122, 1700, 1680, 1465, 1451, 1392, 1361, 1310, 1255, $1202,1170$.

${ }^{1} \mathrm{H}$ NMR: $(400 \mathrm{MHz}, \mathrm{CDCl} 3): \delta 8.27(\mathrm{~s}, 2 \mathrm{H}), 6.01-5.6(\mathrm{~m}, 2 \mathrm{H}) 3.78-3.74(\mathrm{~m}, 3 \mathrm{H}), 2.5(\mathrm{~m}, 2 \mathrm{H}), 1.46(\mathrm{~m}, 2 \mathrm{H})$, $1.32-1.25(\mathrm{br} \mathrm{s}, 30 \mathrm{H}), 0.86(\mathrm{t}, \mathrm{J}=6.6 \mathrm{~Hz}, 6 \mathrm{H})$.

${ }^{13} \mathrm{C}$ NMR $\left(100 \mathrm{MHz}, \mathrm{CDCl}_{3}\right): \delta 162.1,121.3,125.2,77.5,75.3,51.6,39.0,37.8,32.1,29.6,29.8$ 29.5, 26.1, $25.2,22.9,18.3,14.3$.

MS: $\left[\mathrm{C}_{21} \mathrm{H}_{41} \mathrm{NO}_{2}+1\right]^{+} 382.3$

$\mathrm{CHN}: \mathrm{C}=75.53, \mathrm{H}=12.41, \mathrm{~N}=3.67, \mathrm{O}=9.98$.

\subsection{Biology}

Cytotoxicity assay :

Human cancer cell line PC-3 was procured from NCCS, Pune, India. Cells were grown in RPMI 1640 (HiMedia) supplemented with $10 \%$ fetal bovine serum (FBS) with 10,000 U penicillin, $10 \mathrm{mg}$ streptomycin 
and $25 \mu \mathrm{g}$ amphotericin $\mathrm{B}$ per $\mathrm{ml}$ at $37^{\circ} \mathrm{C}$ in a $\mathrm{CO}_{2}$ incubator $(5 \% \mathrm{CO} ; 90 \% \mathrm{RH})$.

In vitro cytotoxicity of the compound was determined by sulforhodamine B (SRB) assay. $100 \mu$ l cell suspension containing $7.5 \times 10^{3}$ cells were added in each well of 96-well plate. The plate was incubated for $48 \mathrm{~h}$ to allow the cells to attach and grow. The cells were then treated with different concentrations of the compound conjugated with equimolar amount of Bovine Serum Albumin, preincubated at $37^{\circ} \mathrm{C}$. After incubation for $48 \mathrm{~h}$, the cells were fixed with $10 \%(\mathrm{w} / \mathrm{v})$ ice-cold trichloroacetic acid (TCA) at $4{ }^{\circ} \mathrm{C}$ for $2 \mathrm{~h} .{ }^{18}$ The wells were washed with water, air dried and $100 \mu \mathrm{l} \mathrm{SRB}$ solution $(0.057 \% \mathrm{w} / \mathrm{v}$ SRB in $1 \%$ acetic acid) was added in each well. The plate was incubated at room temperature for $1 \mathrm{~h}$ and the unbound SRB solution was removed by washing with $1 \%$ acetic acid solution followed by the air drying. Thereafter, $100 \mu$ of $10 \mathrm{mM}$ Tris solution ( $\mathrm{pH}$ 10.5) was added to each well and shaken on a gyratory shaker for $5 \mathrm{~min}$. The absorbance was measured at $510 \mathrm{~nm}$ using a microplate reader. ${ }^{19}$ Inhibition of cell growth was calculated as:

$\%$ cell growth $=($ absorbance of treated cells $/$ absorbance of control $) \times 100 ;$

$\%$ cell inhibition $=100-\%$ cell growth

\section{Declarations}

\section{Competing interest}

The authors declare that they have no known competing financial interest or personal relationships that could have appeared to influence the work reported in this paper.

\section{Acknowlegment}

This work was supported by grants from the DST-SERB project no. EMR/2016/006284 and Punjab Engineering College (Deemed to be University) Chandigarh, India. All spectral analysis was done at CIL Panjab University, Chandigarh. We are thankful to Dr. Nishan Singh, Deputy General Manager and Dr.S. Trehan, President, Panacea Biotec for analysis and scientific deliberations.

\section{References}

1) Saddoughi, S. A., Song, P., \& Ogretmen, B. (2008). Roles of bioactive sphingolipids in cancer biology and therapeutics. Lipids in Health and Disease, 49(1):413-440.

2) Takabe, K., Paugh, S. W., Milstien, S., \& Spiegel, S. (2008). "Inside-out" signaling of sphingosine-1phosphate: therapeutic targets. Pharmacological reviews, 60(2), 181-195.

3) Dellafiora, L., Galaverna, G., \& Dall'Asta, C. (2018). Mechanisms of Fumonisin B1 Toxicity: A Computational Perspective beyond the Ceramide Synthases Inhibition. Chemical research in toxicology, 31(11), 1203-1212. 
4) M.A. Lone, T. Santos, I. Alecu, L.C. Silva, T. Hornemann, 1-Deoxy-sphingolipids, Mol. Cell. Biol. 1864 (2019) 512-521.

5) M. Martinková, J. Gonda, D. Jacková, Simple marine 1-deoxysphingoid bases: biological activity and syntheses, Tetrahedron: Asymmetry 27 (2016) 1187-1212.

6) J.L. Abad, I. Nieves, P. Rayo, J. Casas, G. Fabrias and A. Delgado, Straightforward Access to Spisulosine and 4,5-Dehydrospisulosine Steriosomers: Probe for Profiling Ceramide Synthase Activities in Intact Cells, j.org.chem. 2013, 78, 12, 5858-5866.

7) Rinehart, K. L.; Fregeau, N. L.; Warwick, R. A.; Garcia Gravalos, D.; Avila, J.; Faircloth, G. T. Spisulosine compounds having antitumor activity. PCT WO9952521 A1 19991021, 1999.

8) Rinehart, K. L.; Warwick, R. A.; Avila, J.; Fregeau, G. N. L.; Garcia, G. D.; Faircloth, G. T. Antitumor spisulosine compounds. US 6800661 B1 20041005, 2004

9) Sanchez, A. M.; Malagarie-Cazenave, S.; Olea, N.; Vara, D.; Cuevas, C.; Diaz-Laviada, I. Eur. J. Pharmacol. 2008, 584, 237.

10) Baird, R. D.; Kitzen, J.; Clarke, P. A.; Planting, A.; Reade, S.; Reid, A.; Welsh, L.; Lazaro, L. L.; Heras, B. D. L.; Judson, I. R.; Kaye, S. B.; Eskens, F.; Workman, P.; deBono, J. S.; Verweij, J. Mol. Cancer Ther. 2009, 8, 1430.

11) Williams, R. Expert Opin. Invest. Drugs 2009, 18, 1581.

13) J. Duan, A.H. Merrill, Jr., 1-Deoxysphingolipids Encountered Exogenously and Made De Novo: Dangerous Mysteries Inside an Enigma, J. Biol. Chem. 290 (2015) 15380-15389.

12) R. A. Zuellig, T. Horneman, A. Othman, A. B. Hehl, H. Bode, T. Güntert, O.O. Ogunshola, E.Saponara, K. Grabliauskaite, J. Jang, U. Ungethuem, Y. Wei, A.V. Eckardstein, R. Graf, S. Sonda Deoxysphingolipids, Novel Biomarkers for Type 2 Diabetes, Are Cytotoxic for InsulinProducing Cells, Diabetes, 63 (2014), 568575.

13) J. Liu, B. S. Beckman, M. Foroozesh, A review of ceramide analogs as potential anticancer agents, Future Med. Chem. 5(12) (2013) 1405-1421.

14) M. Mandal, D. J. Olson, T. Sharma, R. K. Vadamuli, R. Kumar, Butyric Acid Induces Apoptosis by Upregulating Bax Expression via Stimulation of the c-Jun N-Terminal Kinase/Activation Protein-1 Pathway in Human Colon Cancer Cells, GASTROENTEROLOGY, 120 (2001) 71-78.

15) G. M. Morris, R. Huey, W. Lindstrom, M. F. Sanner, R. K. Belew, D. S. Goodsell, A. J. Olson, J Comput Chem, 30 (2009) 2785-2791. 
16) T. Ibuka, H. Habashita, A. Otaka, N. Fujii, Y. Oguchi, T. Uyehara and Y. Yamamoto, A highly sterioselective synthesis of (E)-Alkene dipeptide isosteres via organocyanocopper-lewis acid mediated reaction, J. Org. Chem., 56 (1991) 4370-4382.

17) Fernando Martínez-Montañés and Roger Schneiter, Following the flux of long-chain bases through the sphingolipid pathway in vivo using mass spectrometry, jlr.org, 57(5) (2016) 906-915.

18) Skehan P, Storeng R, Scudiero D, Monks A, McMahon J, Vistica D, Warren JT, Bokesch H, Kenney S, Boyd MR. New colorimetric cytotoxicity assay for anticancer-drug screening. J Natl Cancer Inst. 82(13) (1990), 1107-12.

19) Vichai V, Kirtikara K. Sulforhodamine B colorimetric assay for cytotoxicity screening. Nat Protoc. 1(3) (2006) 1112-6.

\section{Figures}<smiles>CCCCC(O)CC(OC(=O)CC(CC(=O)O)C(=O)O)[C@@H](OC(=O)CC(CC(=O)O)CC(=O)O)[C@@H](C)C[C@H](O)CCCC[C@@H](O)C[C@H](O)C(C)N</smiles><smiles>CCCCCCCCCCCCCCCC(O)C(C)N</smiles>

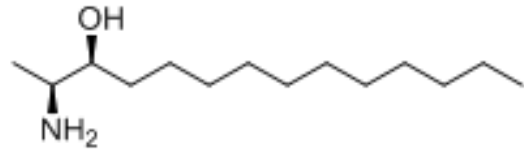

Xestoaminol<smiles>CC[CH]CC(=O)N[C@@H](C)[C@@H](O)/C=C/CCCCCCCCCCCCC</smiles><smiles>CCCCCCCCCCCCC/C=C/C(O)C(C)N</smiles>

4,5-dehydrospisulosine

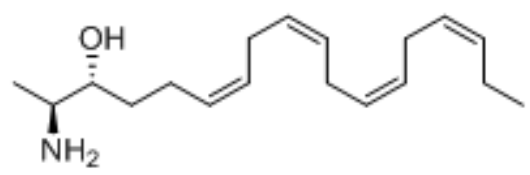

Obscuraminol

\section{Figure 1}

Structures of few 1-deoxysphingolipids. 

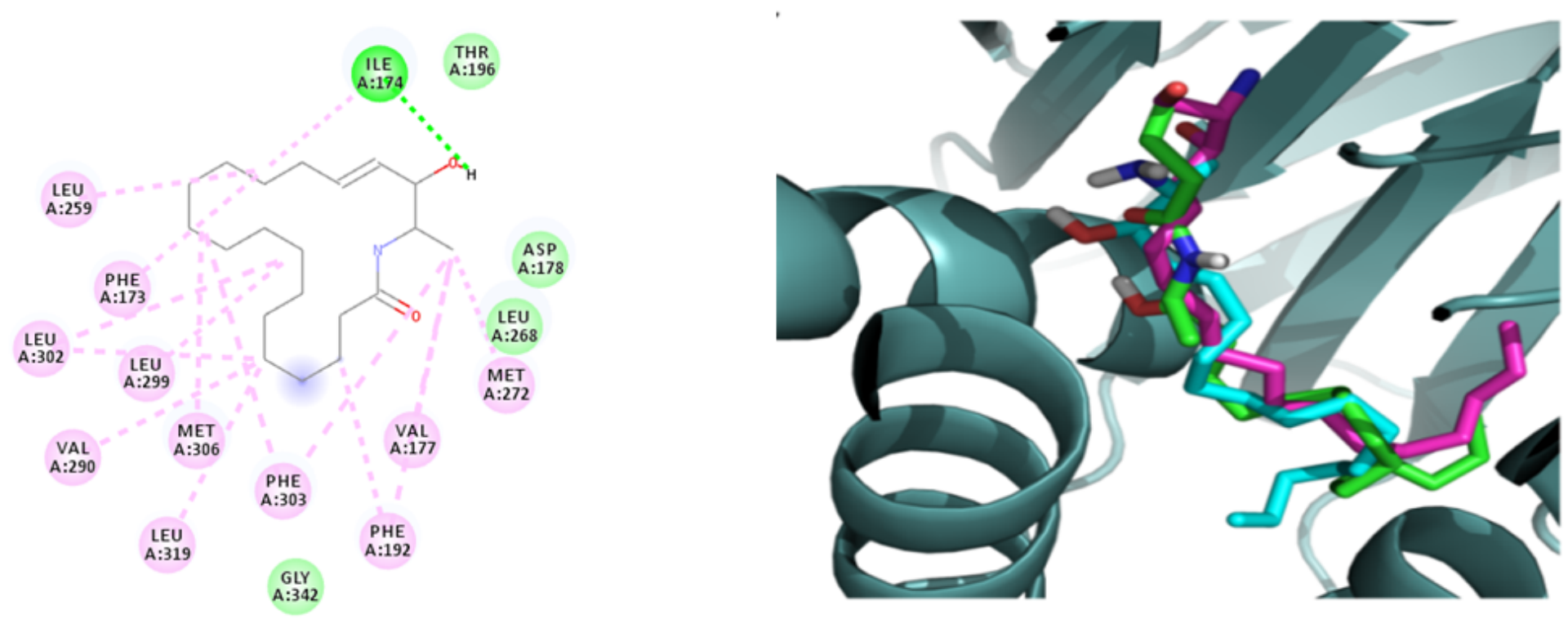

Figure 2

2D structure of the compound $4(A)$ interacting within the binding site (B) compound 4 inlaid into the ligand binding site of SPKH1 (PDB ID: 3VZB)

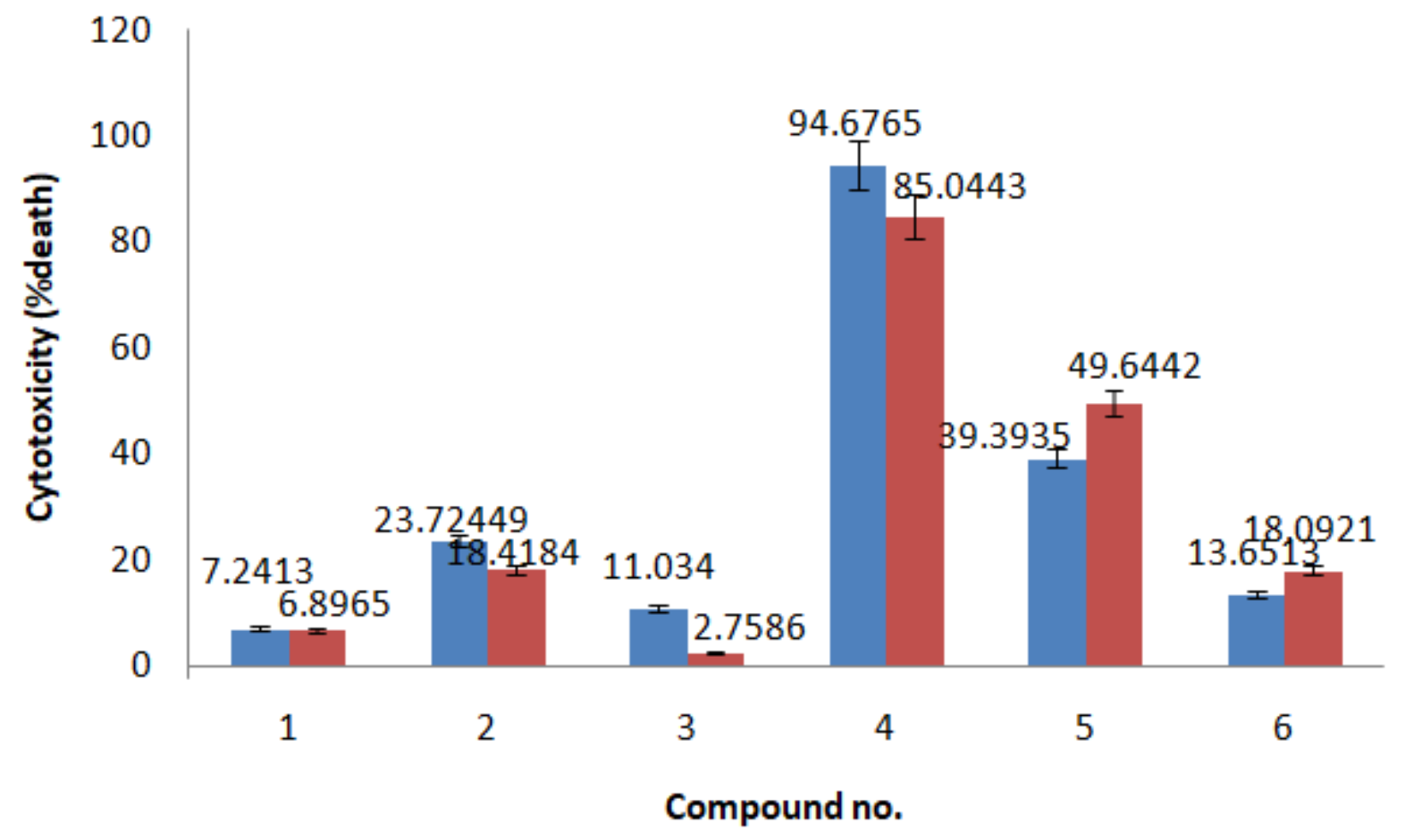

Figure 3

Cytotoxicity (\% cell death) data of compound (1-6) at concentration $100 \mu \mathrm{M}$ (blue) and $50 \mu \mathrm{M}$ (red).

\section{Supplementary Files}

This is a list of supplementary files associated with this preprint. Click to download. 
- Scheme1.png

- Supportinglnformationfewdeoxysphingolipids.docx 